\title{
Sustainability Balanced Scorecard and Management Communication in Evaluating a Company's Performance
}

AFFILIATION:

1. Faculty of Economics and Business, Universitas Pendidikan Ganesha, Indonesia

*CORRESPONDENCE:

sri.werastuti@undiksha.ac.id

THIS ARTICLE IS AVAILABLE IN:

https://ojs.unud.ac.id/index.php/jiab

DOI:

10.24843/JIAB.2021.v16.i01.p03

CITATION:

Werastuti, D. N. S. (2021).

Sustainability Balanced Scorecard and Management Communication in Evaluating A Company's

Performance. Jurnal Ilmiah

Akuntansi dan Bisnis, 16(1), 45-59.

\section{ARTICLE HISTORY}

Received:

01 February 2020

Revised:

28 December 2020

Accepted:

18 January 2020

\author{
Desak Nyoman Sri Werastuti ${ }^{1 *}$
}

\begin{abstract}
This study examines the effectiveness of Sustainability Balance Scorecard (SBSC) and management communication in evaluating company performance. Furthermore, to determine the role of the use of high management communication and the use of the sustainability balanced scorecard in increasing the manager's bonus award decisions. Laboratory experiment was carried out on 94 students of accounting, Faculty of Economics, Ganesha University of Education. Results show that the use of the SBSC influences in evaluating performance. In addition, environmental perspective and the high level of management communication have a significant influence on the decision of managers on bonus allocation.
\end{abstract}

Keywords: environmental perspective, sustainability balanced scorecard, management communication, performance evaluation.

\section{Introduction}

The era of globalization has impacted companies considerably. Companies must be able to keep abreast of an increasingly dynamic business world. Every company is founded with a set of goals determined by the company's CEO based on advices from the company's managers (Anthony \& Govindarajan, 2007:63). Company goals can be profitability, maximizing shareholder value, risk and being responsible to many stakeholders (Anthony \& Govindarajan, 2007:82). Companies must be able to improve their performance and ability to adapt to the existing environment to be able to continue to compete. Manager as the person in charge of the company's operations will always strive so that the company's goals can be achieved. This is done so that the company experiences an increase in value. To find out the achievement of the objectives, performance evaluation is needed.

Performance evaluation is a very important part in the business world. Environmental uncertainty makes one of the main factors that triggers the objectivity of performance evaluation process (Handoko, 2009). Ghosh et al. (2010) revealed that performance evaluation is an important element as managerial control and manager's motivation. 


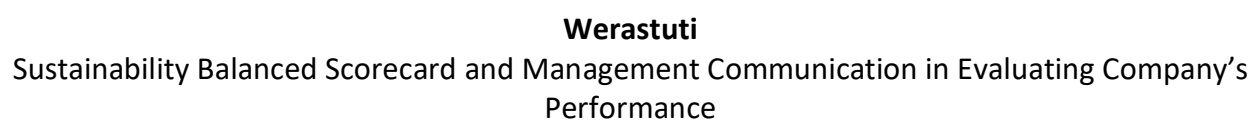

Performance evaluation is a very important factor for a company. Performance evaluation is usually done using financial measures. The use of non-financial measures in performance evaluation became popular the early 1992 when Kaplan and Norton introduced the Balanced Scorecard (BSC) (Kaplan \& Norton, 1992a). BSC is not only a strategy achievement system but it is also a tool that can translate vision, mission and strategy into company goals.

The existing measurement system in the BSC can help managers understanding the company's strategic goals while evaluating the performance achievement. The BSC makes it easy for managers to measure performance to create value for current and future stakeholders, build and improve internal capabilities, and the systems and procedures needed to improve organizational performance (Kaplan \& Norton, 1996).

Measuring the performance of a company is very important for management to evaluate and plan future activities. Communication between subordinates and superiors is needed to ensure that the performance has been carried out effectively and efficiently. Implementation of the BSC in companies in India found evidence that as much as $45.28 \%$ of companies in India have implemented the BSC as a management tool compared to companies in America which were only about 43.90\%. From this research, the financial perspective is considered as the most important perspective in the BSC, followed by the customer perspective, shareholder's perspective, internal business perspective, and growth and learning perspective. In addition, other perspectives that are also considered important for companies in India are the environmental perspective, social perspective, and employee perspective. (Anand et al., 2005; Hoque \& James, 2000; Mooraj, 1999).

Companies that implement BSC generally only use the four main perspectives, companies must also consider the environmental influences caused by company activities, so it is important for companies to pay attention to environmental performance in conducting performance evaluations. One clear example of cases of environmental damage that occurred in Indonesia caused by companies ignoring environmental impacts is the case of forest fires that occurred in 2015 in Riau, Palembang and Kalimantan. This happens because the company only prioritizes the interests of the company and ignores the interests of stakeholders.

The relationship between environmental performance and financial performance is a cause-and-effect relationship, for example poor environmental management can have a very significant impact on financial performance. Environmental performance can also be considered as an important goal for the organization itself, based on moral values that can be promoted by the organization but which must reside with individuals (Tandon et al., 2011). Therefore, companies need to consider performance evaluations based on environmental performance. Performance evaluations based on environmental performance are listed in International Organization for Standardization. Tests regarding the use of BSC in influencing performance evaluation are still limited. This research can provide evidence in the use of BSC for performance and adds environmental perspective in performance appraisal (Lipe \& Salterio, 2000).

An understanding of the impact of using an environmental perspective which is the fifth perspective of the BSC in evaluating is important. Kaplan \& Priscilla (2009) state that companies need to consider using an additional perspective on the BSC to 


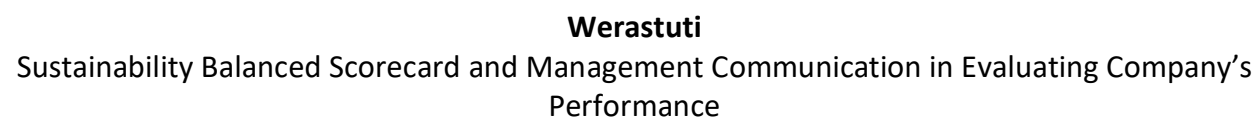

communicate the company's strategic objectives. Andrew Caulfield (2013), D'Aprile \& Mannarini (2012), dan Franz \& Petersen (2012) state that management has various choices related to the overall communication process that can be used to better align managerial actions and strategies.

The motivation of this research is this research can provide evidence in the use of BSC in performance evaluation whose measurement uses perspective from BSC and adds environmental performance in performance appraisal. Furthermore, the objectives of this study are (1) To determine the effect of using the sustainability balanced scorecard on decision making in performance evaluation (2) To determine the effect of the use of management communication on the use of the sustainability balanced scorecard in performance evaluation (3) To determine the effect of the use of high management communication. and the use of the sustainability balanced scorecard to increase manager's bonus award decisions.

Stakeholder Theory focuses on the different stakeholder groups referred to by managers. Stakeholder theory is a theory of organizational management and business ethics (Uzma, 2016). Stakeholder theory explains that managers have an incentive to provide disclosure of certain information to stakeholders (Freeman, 1984). The main idea of this theory is the need for organizations to manage relationships with stakeholder groups, namely groups or individuals who can influence or be affected in relation to the achievement of company goals. Organizational success depends on how well the organization manages relationships with key groups such as customers, employees, community suppliers, financiers and others who can influence the achievement of objectives (Freeman \& Robert, 2002) including the environment (Dellaportas et al., 2005).

The stakeholder theory approach is a rational approach to organizational managers which states that when managers manage organizations effectively they must systematically consider stakeholders (Bornhorst et al., 2010; Jones \& Wicks, 2010a; Michelon et al., 2013; Nwanji \& Howell, 2014). This theory predicts that managers will consider stakeholders who in this case are environmental and social groups. There are two groups of stakeholders namely voluntary stakeholders and non-voluntary stakeholders. Voluntary stakeholders are a group or individuals who bear some type of risk because they have invested in a company. While non-voluntary stakeholders are groups or individuals who face risks due to company activities. In other words, stakeholders are parties who influence or will be influenced by company decisions and strategies (Clarkson et al., 2004).

Agency theory is based on the premise that there is a difference in information between superiors and subordinates or between head office and branch offices or information asymmetry influences the use of accounting systems (Shields \& Young, 1993). This theory basing on economic theory. From the standpoint of agency theory, principal (owner or top management) supervising agents (employees or lower managers) to carry out efficient performance. This theory assumes that organizational performance determined by the effort and influence of environmental conditions. This theory in general assumes that the owner is risk-neutral while the agent like risk. Agents and owners are assumed to be motivated by their own interests and often the interests between the two clash (Kren, 1992). 


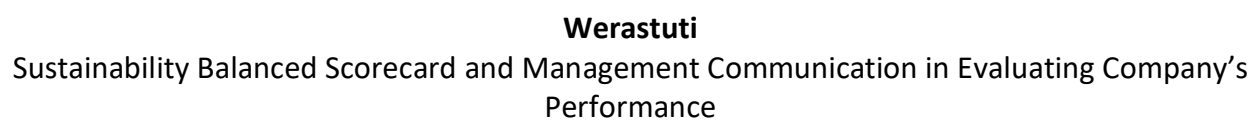

Management control as a process by which managers in an organization influence other members of the organization to implement organizational strategies (Anthony \& Govindarajan, 2007). Management control system is a system used to plan various activities to realize the vision of the organization through selected missions and to implement and control the implementation of the plan (Abernethy \& Lilis, 1998).

The main objective of the management control system is to ensure that the alignment of objectives can be achieved to the maximum extent possible. Companies also need to consider the extent of control that needs to be done, because the tighter the control will limit the creativity of employees as members of the organization. An important management control system is owned by the company as a tool to control and ensure the process of implementing the company's strategy so that it can run well.

The performance measurement process needs to be carried out to ensure the implementation of the company's strategic plan has been going as expected. One performance measurement system that can be used by companies in conducting comprehensive performance evaluations is to use a BSC. Each company uses general and unique measures in evaluating performance (Lipe \& Salterio, 2000). Initially, performance measurement only focuses on traditional valuations or only uses financial measures because it is assumed that financial measures are easy to measure and implement.

Kaplan and Norton state that using financial measures alone is not enough in conducting performance evaluations, because financial measures only focus on shortterm financial goals only. Measurement of financial performance is related to traditional measurement with a focus on the company's short-term measures (Lau \& Sholihin, 2005). In addition, other opinions state that there is a dysfunctional action caused by the company only using financial measures only in evaluating performance (Anthony \& Govindarajan, 2007).

The dysfunctional action in question is to encourage managers to take shortterm actions that are not in accordance with the company's long-term goals, allows for business unit managers to take decisions that prioritize the company's short-term profits without thinking about the company's long-term profits, also can enable managers to manipulate financial data in decision making.

The BSC concept was first introduced by Robert S Kaplan and David P Norton in 1992. Kaplan and Norton define the BSC as a set of performance measurement tools that provide a comprehensive view of the business world, whose measurements are not only seen from financial aspects but also viewed from non-financial aspects. Aside from being a performance measurement tool, BSC is a tool used to assist in translating and implementing the vision and strategy of an organization which is divided into four perspectives namely financial perspective, customer perspective, internal business process perspective and growth and learning perspective.

Simply put, the BSC concept will help managers and executives in developing strategy and implementation formulations to achieve harmony both vertically and horizontally. However, what distinguishes BSC from traditional measurements is the existence of a balance between performance measures used, a balance between the lag indicator relationship and the lead indicator. One of the main keys of BSC is that there is a causal relationship between the four perspectives. Financial perspective is a lag 


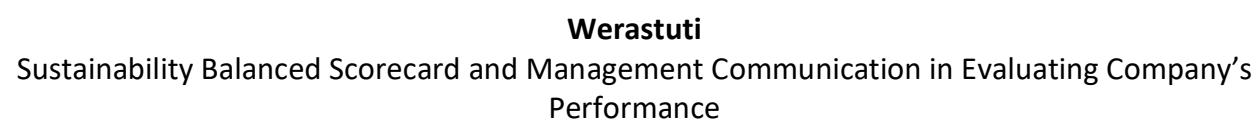

indicator that is the main goal of the company. Achievement in a financial perspective will not succeed without the achievement of the other three perspectives.

The development of environmental issues is a concern of the public in encouraging corporate awareness to carry out environmental management in the business world. It is important for management accountants of an organization or company to consider environmental aspects in conducting performance evaluations conducted by managers. Schaltegger \& Burritt (2006) explains that developments on environmental issues encourage the development of conventional accounting to not only consider economic and non-economic aspects in evaluating performance, but also expand on accounting aspects of environmental impacts. This environmental accounting focuses on environmental aspects known as eco-efficiency.

Eco efficiency is a concept relating to maintaining the production of goods and services that are more useful while reducing the environmental impact caused by these activities. Hansen \& Mowen (2007) revealed that the concept of eco efficiency was an attempt by the company to direct its operations to be more environmentally friendly. In addition, this concept also explains that the company's efforts to produce goods and services that have added value at the same time are sustainable in reducing negative impacts on the environment through efficient use of resources.

In a company, communication between managers and subordinates is a very important thing that must be done by the company. With communication it allows all members in the organization to interact with each other until the company's goals can be achieved. Communication is the process of delivering or exchanging information from the sender to the recipient, both verbally, in writing or using communication tools (Dinar, 2014).

Communication within the organization becomes a flow system that connects and generates performance between parts of the organization so that it can produce synergies, thus communication in addition to building organizational climate also helps build organizational culture (Dinar, 2014). One form of communication in organizations is communication between superiors and subordinates in an organization. Communication between superiors and subordinates involves the flow of formal communication.

Research on BSC is generally concerned with identifying performance measures related to the implementation of strategies, targets and measurements (R. S. Kaplan \& Norton, 1992b). In management performance, BSC plays an important role to increase stakeholder value, adjusting environmental interests in it based on environmental indicators (Schaltegger \& Burritt, 2015).

The view of stakeholder theory states that in order to meet stakeholder interests, corporations must deal with differences in interests among stakeholders. Differences in interests between managers and stakeholders, as well as among stakeholders themselves, are a challenge for the corporation, because each party wants to maximize their interests. Stakeholder theory provides an analysis of who the group is the recipient of social action, and attempts to bring together the needs and expectations of a wider stakeholder group (Nwanji \& Howell, 2014).

Research conducted by Henri \& Journeault (2010) on eco-control influences management control systems on environmental performance and economic performance found evidence that there is a mediating impact of environmental 


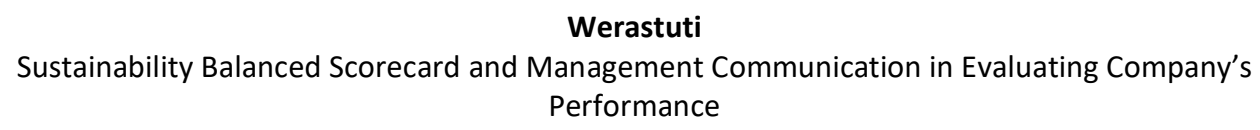

performance on the relationship between eco-control and economic performance. More specifically eco-control has a direct influence on economic performance in the context of higher environmental exposure, higher public visibility, and higher environmental awareness (Nwanji \& Howell, 2014). Good or bad information about environmental impacts helps managers in making decisions, so managers will be able to make better decisions in accordance with the information obtained. Based on the explanation above, the hypothesis proposed is

$\mathrm{H}_{1}$ : The use of an environmental perspective in the sustainability balanced scorecard will influence evaluators in conducting performance evaluations

The broader stakeholder theory provides an explanation that corporate performance is also determined by the stakeholders. The existence of a corporation is not only to maximize the welfare of shareholders, but also serves the interests of corporate stakeholders (Jones \& Wicks, 2010b).

Performance evaluation is related to the different strategic environmental objectives of each organization. The strategic objectives undertaken by evaluating performance based on environmental impacts are to control environmental pollution, pollution prevention, eco-efficiency, eco-innovation, eco-ethics and corporate sustainability (Dias-Sardinha \& Reijnders, 2005). Specifically (Lipe \& Salterio, 2000) states that the content format of the BSC tends to view information as a relationship between performance measures in certain situations such as when performance measures consist of positive and negative relationships.

The thematic use of the BSC format is useful for better understanding the strengths and weaknesses of the relationship between goals and measurement, initiatives and achievements (Dias-Sardinha \& Reijnders, 2016). Improved environmental performance is aligned with improved social performance, based on that, Lipe and Salterio stated that there are sustainability levels of performance in various companies in Portugal, which are also a driving force to manage environmental performance management (Dias-Sardinha et al., 2002).

Lipe \& Salterio (2000) state that there is still little research that examines the impact of management communication in achieving the company's strategic goals. Communication managers in delivering the company's vision and strategy to employees is very important so that employees can understand the company's strategy so that company goals can be achieved. Other studies have found important evidence of the importance of manager communication in achieving effective use of BSC (Malina \& Frank, 2001).

Different results were presented by Kaplan \& Priscilla (2009) who found evidence that additional separate environmental perspectives were ineffective unless decision makers received additional information about the strategic importance of environmental measures. In addition, the results of the study also found evidence that environmental perspectives are ignored unless there is managerial communication. Therefore, based on the description above the researcher concludes that it is important for managers to communicate the strategic objectives of using BSC in performance evaluation. Based on the previous explanation, the second hypothesis proposed in this study is: 


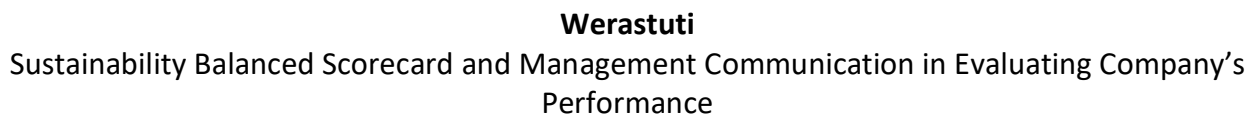

$\mathrm{H}_{2}$ : When management communication about environmental information is high, the use of environmental perspective will influence performance evaluation using SBSC compared to when management communication is low.

According to agency theory, the agent and owner are assumed to be motivated by their own interests and often the interests between the two clash (Kren, 1992). In the owner's view, the compensation given to the agent is based on results, whereas according to the agent he prefers that the compensation system does not merely look at results but also the level of effort.

Conceptually, when performance evaluations are carried out using a BSC, they must be linked to manager compensation (Kaplan \& Norton, 2001). Supervisors may become reluctant to use formal performance measurement tools that do not allow them to provide compensation based on company policy so it is important to make compensation decisions (Scharf et al., 2013).

Lipe \& Salterio (2000) do not link compensation with assessments based on the BSC. However, it is different from Andrew \& Robert (2013) who conducted an experiment about giving bonuses in performance evaluation which found evidence that participants used an assessment based on the BSC to determine the bonus or compensation to be received by managers. When the company implements BSC and is able to communicate well the objectives and targets that will be used in assessing performance, then this will have implications for determining bonuses. When the intensity of communication is high, the compensation decision will be influenced by a comprehensive assessment based on the BSC. Based on the description, the next hypothesis proposed in this study is:

$\mathrm{H}_{3}$ : The existence of high management communication and the use of environmental perspectives in the sustainability balanced scorecard will influence the decision of bonus allocation for managers.

\section{Research Method}

This study used an experimental approach by adopting instruments developed by Lipe and Salterio with additional modifications in accordance with the research objectives and adapted to conditions in Indonesia. Furthermore, for information on environmental perspectives and management communication researchers used the Kaplan \& Priscilla (2009) instruments. Experiments were manipulated with the conditions of management communication and the use of environmental perspectives in the BSC by using an experimental design $2 \times 2$ between subjects with the first factor being performance evaluation using a BSC perspective (without an environmental perspective/4 BSC perspectives and with an environmental perspective/5 BSC perspectives), the second factor is management communication (high and low).

Participants in this study were 124 undergraduate accounting students at the Faculty of Economics, Ganesha University of Education who were randomly selected, with criteria for taking Management Accounting and Sustainability Accounting courses. The subject of this study was chosen because it was assumed that students knew the performance evaluation using SBSC and had an understanding of the concept of measuring performance using SBSC. Besides the selection of students as research subjects because based on psychological literature shows that students are able to process the same information as professional individuals in psychological experiments. 


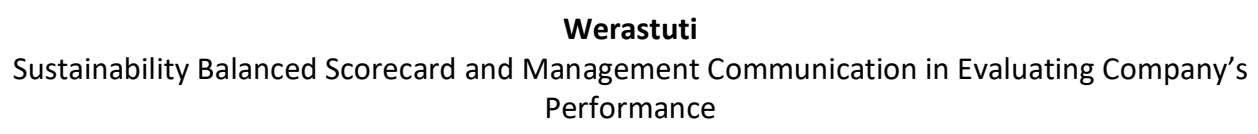

Participants read and act as company evaluators of a manufacturing company called PT Pupuk Kaltim, a company that specialized in manufacturing fertilizers and ammonia. Case material provided illustrates the company's financial performance and operational performance deteriorating, operational problems occur involving the quality of production and penalties for violating environmental damage. The company then developed SBSC to assist in implementing the company's strategic objectives and managing company performance.

In the case, the management team consists of team managers and managers. All existing instrument cases indicate that managers consider environmental performance to be one of the company's strategic objectives. The selection of environmental performance appraisal is important in setting the strategic objectives of the organization in this study, especially for manufacturing companies that utilize natural products as one of the main raw materials in production activities.

All instruments used consisted of 20 common measurements in performance evaluation. Assessment is done by comparing the percentage of targets to be achieved with the realization of the target achievement of the two planning managers by assessing whether the good or bad achievement or realization of what was previously targeted. After reading the case. PT. Pupuk Kaltim, participants were asked to provide judgments or judgments for two managers who had been previously appointed. The requested assessment is done by giving an overall performance evaluation score on a scale of one to seven where the zero scale represents the need for managers to be "reassigned" and the hundred scale represents the performance of the managers of "extraordinary". After assessing the performance of both managers, participants were asked to complete closing questions and demographics.

Closing questions aim to obtain information about manipulation checks, task difficulty level, reality and subject understanding of the given case, as well as capturing the emotional reactions felt by the subject. Demographic questions are given to obtain information about gender, age, S-1 field of study and length of work experience.

\section{Result and Discussion}

To find out the subject's understanding of case manipulation, there are four manipulation questions raised at the end of the experiment relating to environmental performance, the strategies used, performance measures used and the level of management communication.

Participants are said to have passed manipulation if they answered correctly to all four questions. Based on the results of manipulation checks as many as 15 participants who did not pass manipulation. In addition, from the total participants who passed the manipulation, four participants could not be used and had to be excluded from the sample because the participants did not fill out the evaluation sheet completely and did not fill in demographic data correctly. So that the total final sample that can be used is 94 participants or $83.19 \%$ of the total sample collected by the researcher.

In addition, there are four additional questions to check manipulation as a whole to ascertain whether the design of the experiment has been successful or not. Four additional questions related to participant's knowledge of the BSC concept, participants' understanding of the BSC, the level of ease of the case given, and the level 


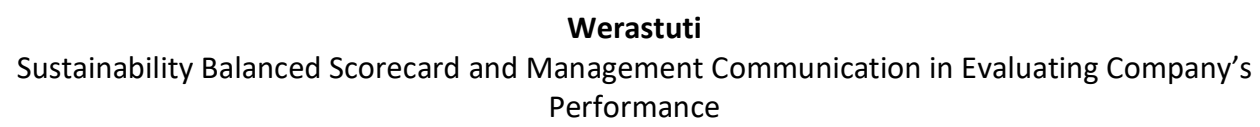

of reality of the case that was given. The four questions are measured on a scale of 1 (strongly disagree) to a scale of 5 (strongly agree). The overall manipulation check is said to be successful if the participants' answers to the four questions differ significantly with 1 (the answer parameter does not agree). The test was carried out using one sample $t$ test which showed the results that participants' answers to the four additional manipulation questions differed significantly $(p<0,05)$. This shows that the manipulation or treatment provided in this study was successfully carried out.

124 undergraduate students from the Department of Accounting, Ganesha University of Education participated in this experiment. But after checking the manipulation and completeness of other data only 94 participants whose data can be used by researchers. Furthermore, before further analysis, the data were tested randomly first. Randomization is an important element in experimental research. Randomization is done by placing the subject into the experimental group and the control group randomly without paying attention to the factors attached to the subject in order to guarantee independence that does not pay attention to demographic characteristics, so that the differences occur purely due to manipulation provided (Nahartyo, 2013).

Randomization testing was carried out with Chi-Square analysis to show that there were no differences between groups of subjects that were experimented based on gender, age, majors, SBSC knowledge, and work experience. The results of the sex chisquare randomization test showed no significant differences between groups $(X 2=$ $19.63 ; p>0.05)$. The randomization test for age shows a value $(X 2=55.71 ; p>0.05)$ which means there is no significant difference between groups. Furthermore, the randomization test for majors also showed no differences between groups with grades $(X 2=17.94 ; p>0.05)$. The randomization test results on SBSC knowledge also showed the results that there were no significant differences between groups $(X 2=18 ; p>0.05)$. The last randomization test result is work experience also not Lipe and Salterio significant differences between groups $(X 2=58.92 ; p>0.05)$.

The first hypothesis $\left(\mathrm{H}_{1}\right)$ predicts the use of an environmental perspective in SBSC to influence performance evaluation. Subjects who are in a condition to get environmental perspectives or receive SBSC with five perspectives will influence evaluators in conducting performance evaluations. The results of data analysis showed that the influence of environmental perspective variables have a significant effect of 0.05 with $p=0.01<0.05$ and $F=3.138$. It can be concluded that there are differences in the use of environmental perspectives in evaluating performance using SBSC, so that the first hypothesis in this study is supported.

The second hypothesis $\left(\mathrm{H}_{2}\right)$ predicts that the use of management communication influences the performance evaluation using SBSC. The results of data analysis showed that the effect of high management communication variables did not have a significant effect, namely $p>0.05$ where the value of $p=0.383$ with the value of $F$ $=0.770$. It can be concluded that there is no influence of management communication in performance evaluation, so the second hypothesis in this study is not supported. Besides that, the result of interaction between environmental perspective and management communication on performance evaluation gives an $F$ value of 0.081 with a value of sig.0.777, which means there is no joint effect or joint effect between environmental 
Werastuti

Sustainability Balanced Scorecard and Management Communication in Evaluating Company's Performance

Table 1. ANOVA Test Results

\begin{tabular}{|c|c|c|c|c|c|}
\hline Source & $\begin{array}{l}\text { Type III Sum of } \\
\text { Square }\end{array}$ & $d f$ & $\begin{array}{l}\text { Mean } \\
\text { Square }\end{array}$ & $\mathrm{F}$ & Sig. \\
\hline Corrected Model & $7,632.540$ & 3 & $1,844.242$ & 1.445 & 0.256 \\
\hline Intercept & $5,103,633.760$ & 1 & $5,103,615.756$ & $3,563.600$ & \\
\hline KM & $1,140.542$ & 1 & $1,324.654$ & 0.74 & 0.360 \\
\hline BSC perspective & $4,652.000$ & 1 & $4,623.000$ & 3.254 & 0.010 \\
\hline KM * Perspective & 124.100 & 1 & 132.200 & 0.021 & 0.721 \\
\hline Error & $131,442.530$ & 88 & $1,442.012$ & & \\
\hline Total & $5,223,873.000$ & 92 & & & \\
\hline Corrected Total & $136,483.400$ & 91 & & & \\
\hline
\end{tabular}

Source: Processed Data, 2019

perspective and management communication on performance evaluation.

The third hypothesis $\left(\mathrm{H}_{3}\right)$ in this study predicts that the use of environmental perspective and management communication influences the decision of bonus allocation to be received by managers. The third hypothesis was tested using simple regression analysis with the dependent variable being the difference in the amount of bonus allocations given by participants to both managers and the independent variable was the difference in performance appraisal from the two divisions.

Based on the results of the analysis conducted shows that the existence of management communication and the use of environmental perspective in SBSC is significant in the bonus allocation decision by evaluators with sig. $p=0.00$ and the value of $F=48.269$. The bonus allocation value in this study shows the Adj R2 value of 0.337 . The simple regression test results presented in Table 2. show that performance appraisals conducted by participants who use environmental perspectives in performance evaluation using SBSC and have a high level of management communication significantly influence the bonus allocation decision with a value of $t=$ 6.948 and $p=0,00$ So that the third hypothesis in this study is supported.

This research successfully found evidence that the use of environmental perspective and management communication in SBSC performance evaluation influences evaluators in allocating bonuses to be received by division managers. The results of this study are consistent with research (Figge et al., 2012) who conducted experiments on bonus giving in performance evaluations that found evidence that participants used SBSC-based assessments to determine bonuses or compensation to be received by managers. The results of this study further clarify the role of high management communication presence and the use of SBSC's environmental perspective

Table 2. Test Results of Regression Analysis

\begin{tabular}{|c|c|c|c|c|c|}
\hline \multirow{2}{*}{ Model } & \multicolumn{2}{|c|}{ Unstandardized Coefficients } & \multirow{2}{*}{$\begin{array}{l}\text { Standardized } \\
\text { Coefficients } \\
\text { Beta }\end{array}$} & \multirow[t]{2}{*}{$\mathrm{t}$} & \multirow[t]{2}{*}{ Sig. } \\
\hline & $B$ & Std Error & & & \\
\hline 1 (Constant) & $4,691,934.700$ & $1,919,384.200$ & & 2.289 & 0.024 \\
\hline Performance evaluation & $434,947.320$ & $52,894.080$ & 0.578 & 6.473 & 0.012 \\
\hline
\end{tabular}

Source: Processed data, 2019 


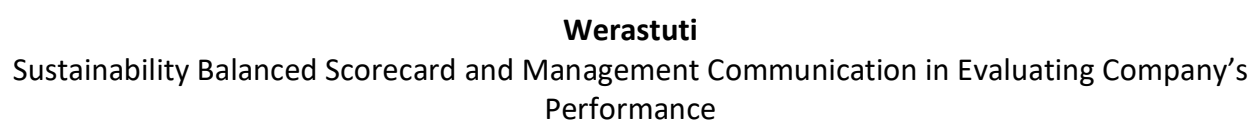

in performance evaluations used for bonus allocation decisions to be received by managers.

In contrast to the determination of bonuses based on performance evaluations, the results of this study failed to find evidence of a significant influence on the use of management communication in increasing the role of environmental perspectives in SBSC related to performance evaluation. The results of this study are in line with research conducted by Kaplan \& Priscilla (2009) who found evidence that management communication had no effect on the effectiveness of using SBSC in performance evaluation.

There is an explanation why high management communication does not influence the effectiveness of using SBSC with an environmental perspective in performance evaluation. Based on the organizational communication literature there are several characteristics that influence the quality and effectiveness of management communication in organizations, namely (1) the communication process and communication messages (2) support from organizational culture (3) the creation and sharing of knowledge (Malina \& Frank, 2001).

Next, this study found a significant influence in the use of environmental perspective in performance evaluation based on SBSC. The existence of an environmental perspective is able to influence evaluators in conducting performance evaluations. This is in line with stakeholder theory which states that when managers manage organizations effectively they must systematically consider stakeholders (Freeman, 1984). This theory predicts that managers will consider stakeholders who in this case are environmental and social groups.

\section{Conclusion}

This research has succeeded in finding evidence that the use of environmental perspective in SBSC is able to provide a significant influence in performance evaluation. In addition, there is high management communication when the BSC is presented with an additional environmental perspective that has not been able to provide a significant influence in evaluating performance using SBSC. However, the presence of high management communication and the use of SBSC with an additional environmental perspective had a significant influence on the decision of allocating bonuses by the evaluator team allocated to managers of both divisions.

Theoretical implications in this study are theoretically, this research provides information for the development of knowledge in accounting, especially regarding stakeholder theory and agency theory. This research is expected to provide a more complete explanation of these theories to support similar research in the future

Practically, this research has several implications. For stakeholders namely shareholders or investors and potential investors to assist in decision making and is expected to help predict the sustainability of the company. The company is expected to be able to give more and better attention and knowledge in evaluating the sustainability report as a form of corporate concern for the environment around the company as well as an effort to increase the company's value in the eyes of investors.

The influence of information sources that might be taken into consideration is not considered as described by Fisher (1996). Participants in this study were not involved in the development of the BSC, whereas involvement in the development of 


\author{
Werastuti \\ Sustainability Balanced Scorecard and Management Communication in Evaluating Company's \\ Performance
}

the BSC would encourage them to consider all BSC measurements including unique and non-financial measures. Participants in this study came from groups of S1 students who were less experienced in evaluating performance using BSC. Although all participants already know about the concept of performance evaluation in the BSC, the level of understanding of the participants related to the BSC varies which cannot be known with certainty. Experiments are conducted in the afternoon and afternoon after the lecture ends, thus allowing participants to experience fatigue when working on experimental tasks.

Future studies are expected to use survey methods for management accountants or people who have experience in performance evaluation, so that research results can be compared. Future studies can use a wider sample and participants who are actual management accountants or people who have experience in conducting performance evaluations, so that the level of generalization can be better.

\title{
References
}

Abernethy, M. A., \& Lilis, A. M. (1998). Complementarities in control system design: a test in hospitals.

Anand, M., Sahay, B. S., \& Subhashish, S. (2005). Balanced Scorecard in Indian Companies. Business and Management, 30(2), 11-25. https://doi.org/10.1177/0256090920050202

Andrew Caulfield, P. (2013). The evolution of strategic corporate social responsibility. EuroMed Journal of Business, 8(3), 220-242. https://doi.org/10.1108/EMJB-052013-0030

Andrew, E., \& Robert, A. F. (2013). Corporate culture and Job Satisfaction. Journal of Applied Psychology Research, 12, 63-77.

Anthony, N. R., \& Govindarajan, V. (2007). Management Control System (12th ed.). McGraw Hill International Edition.

Bornhorst, T., Ritchie, J. R. B., \& Sheehan, L. (2010). Determinants of tourism success for DMOs \& destinations: An empirical examination of stakeholders' perspectives. Tourism Management, 31(5), 572-589.

Clarkson, P., Li, Y., \& Gardon, R. (2004). The Market Valuation of Environmental Capital Expenditures by Pulp and Paper Companies. The Accounting Review, 79 (2) 329353. https://doi.org/10.2308/accr.2004.79.2.329

D’Aprile, G., \& Mannarini, T. (2012). Corporate social responsibility: a psychosocial multidimensional construct. Journal of Global Responsibility, 3(1), 48-65. https://doi.org/10.1108/20412561211219283

Dellaportas, S. K., Gibson, R., Alagiah, M., Hutchionson, P., Leung, D., \& Homrigh, V. (2005). Ethics, Governance \& Accounting: A Professional Perspective. John Wiley \& Son Australia Ltd, Australia.

Dias-Sardinha, I., \& Reijnders, L. (2005). Evaluating Enviromental and Social Performance of Large Portuguese Companies: a BSC Approach. Business Strategy and The Enviroment. 14(2), 73-91. https://doi.org/10.1002/bse.421 
Werastuti

Sustainability Balanced Scorecard and Management Communication in Evaluating Company's Performance

Dias-Sardinha, I., \& Reijnders, L. (2016). Developing sustainability balanced scorecards for environmental services: a study of three large Portuguese companies. Environ. Qual. Manag., 16(4), 13-34.

Dias-Sardinha, I., Reijnders, L., \& Paula, A. (2002). From Environmental Performance Evaluation to Eco-Efficiency and Sustainability BSC. Environmental Quality Management, 12(2), 51-64. https://doi.org/10.1002/tqem.10063

Dinar, A. S. (2014). Hubungan Komunikasi Atasan Bawahan yang Efektif dan Kompensasi Langsung dengan Komitmen Organisasional Melalui Kepuasan Kerja Sebagai Variabel Intervening: Studi Persepsian pada Karyawan BPR di Bawah Grup Saudara Wilayah Jawa Tengah dan DIY. Universitas Gadjah Mada.

Figge, F., Hahn, T., Schaltegger, S., \& Wagner, M. (2012). The sustainability balanced scorecard-linking sustanability management to business strategy. Business Strategy and the Environment, 11(5), 269-284. https://doi.org/10.1002/bse.339

Franz, R. S., \& Petersen, H. L. (2012). Role of business: a portfolio model of corporate social responsibility. Journal of Global Responsibility, 3(1), 83-110. https://doi.org/10.1108/20412561211219300

Freeman, R. E. (1984). Stakeholder Theory of the Modern Corporation. General Issues in Business Ethics, 38-48.

Freeman, R. E., \& Robert, A. P. (2002). Stakeholder Theory: A Libertarian Defense. Business Ethics Quarterly, 13(2), 331-349. https://doi.org/10.2307/3858020

Ghosh, D., Joanna, L. Y. H., \& Hiroshi, M. (2010). Strategy, Incentive Design and Performance: Empirical Evidence. AAA 2011 Management Accounting Section (MAS) Meeting Paper. http://dx.doi.org/10.2139/ssrn.1659689

Handoko, J. (2009). Debiasing Outcome Effect Dalam Penilaian Kinerja: Suatu Studi Eksperimen. Simposium Nasional Akuntansi XII.

Hansen, D. R., \& Mowen, M. M. (2007). Management Accounting (8th ed.). SouthWestern,USA: Thomson Learning.

Henri, J. F., \& Journeault, M. (2010). Eco-Control: The Influence of Management Control System on Environmental and Economic Performance. Accounting Organizations and Society, 35(1), 63-80. https://doi.org/10.1016/j.aos.2009.02.001

Hoque, Z., \& James, W. (2000). Linking Balanced Scorecard Measures to Size and Market Factors: Impact on Organizational Performance. Journal of Management Accounting Research, 12, 1-17.

Jones, T. M., \& Wicks, A. C. (2010). Convergent Stakeholder Theory. Academy of Management Review, 24(2), 206-222. https://doi.org/10.2307/259075

Kaplan, R., \& Norton, D. (2001). The Strategy Focused Organization: How Balanced Scorecard Companies Thrive in the New Business Environment. Harvard Business School Press, Boston, MA.

Kaplan, R. S., \& Norton, D. P. (1992a). The balanced scorecard-measures that drive performance. Harvard Business Review, 70(1), 71-79.

Kaplan, R. S., \& Norton, D. P. (1996). Using BSC as a Strategic Management System. Harvard Business Review. 


\section{Werastuti \\ Sustainability Balanced Scorecard and Management Communication in Evaluating Company's Performance}

Kaplan, R. S., \& Priscilla, S. W. (2009). The Judgmental Effect of Management Communications and a Fifth BSC Category on Performance Evaluation. Behavioral Research in Acccounting, 21(2), 37-56. https://doi.org/10.2308/bria.2009.21.2.37

Kren, L. (1992). Budgetary Participation and Managerial Performance: The Impact of Information and Environmental Volatility. The Accounting Review, 67(3). 511526. https://www.jstor.org/stable/247975

Lau, C. M., \& Sholihin, M. (2005). Financial and Nonfinancial Performance Measure: How do they affect job satisfaction? The British Accounting Review, 37(2), 389-413. https://doi.org/10.1016/j.bar.2005.06.002

Lipe, M. G., \& Salterio, S. (2000). The BSC: Judgmental Effect of Common and Unique Performance Measure. The Accounting Review, 75(3), 283-298.

Malina, M. A., \& Frank, H. S. (2001). Communicating and Controlling Strategy: An Empirical Study of Effectiveness of The BSC. Journal of Management Accounting Research, 13(1), 47-90. https://doi.org/10.2308/jmar.2001.13.1.47

Michelon, G., Boesso, G., \& Kumar, K. (2013). Examining the link between strategic corporate social responsibility and company performance: An analysis of the best corporate citizens. Corporate Social Responsibility and Environmental Management, 20(2), 81-94. https://doi.org/10.1002/csr.1278

Mooraj, E. (1999). The Balanced Scorecard: A Necessary Good or An Unnecessary Evil. European Management Journal, 17(5), 481-491. https://doi.org/10.1016/S02632373(99)00034-1

Nahartyo, E. (2013). Desain dan Implementasi Riset Eksperimen (2nd ed.). . UPP STIM YKPN, Yogyakarta.

Nwanji, T. I., \& Howell, K. E. (2014). The Stakeholder Theory in the Modern Global Business Environment. International Management Journals, 1(1).

Schaltegger, S., \& Burritt, R. (2006). Corporate Sustainability Accoounting a Catchphrase for Compliant Corporations or a Business Decision Support for Sustainability Leaders? Sustainability Accounting and Reporting, 37-59. https://doi.org/10.1007/978-1-4020-4974-3_2

Schaltegger, S., \& Burritt, R. (2015). Business cases and corporate engagement with sustainability. Differentiating ethical motivations. Journal of Business Ethics, 147, 241-259. https://doi.org/10.1007/s10551-015-2938-0

Scharf, E. R., Fernandes, J., \& Kormann, B. D. (2013). Corporate social responsibility to build strong Brazilian bank brand. International Journal of Bank Marketing, 30(6), 436-451. http://dx.doi.org/10.1108/02652321211262203

Shields, M. D., \& Young, S. M. (1993). Antecedents and Consequences of Participative Budgeting: Evidence on the Effect of Asymmetrical Information. Journal of Management Accounting Research, 23(1), 49-76. https://doi.org/10.1016/S0361-3682(97)00014-7.

Tandon, A. K., Mishra, S. K., \& Singh, E. (2011). What Discriminates the Prospective Manager's Attitude Towards Corporate Social Responsibility? An Insight From Pyschological Variables. Journal of Corporate Governance, 10(3), 52-70. 


\section{Werastuti}

Sustainability Balanced Scorecard and Management Communication in Evaluating Company's Performance

Uzma, S. H. (2016). Embedding corporate governance and corporate social responsibility in emerging countries. International Journal of Law and Management, 58(3), 299-316. https://doi.org/10.1108/IJLMA-04-2015-0015 